\title{
Review Article \\ Human Interferon Alpha-2b: A Therapeutic Protein for Cancer Treatment
}

\author{
Ratih Asmana Ningrum \\ Research Center for Biotechnology, Cibinong Science Center, Jalan Raya Bogor km 46, Cibinong, Bogor, West Java 16911, Indonesia \\ Correspondence should be addressed to Ratih Asmana Ningrum; ratih.asmana@gmail.com
}

Received 3 January 2014; Accepted 22 January 2014; Published 10 March 2014

Academic Editors: A. Asai and A. Espinosa

Copyright (C) 2014 Ratih Asmana Ningrum. This is an open access article distributed under the Creative Commons Attribution License, which permits unrestricted use, distribution, and reproduction in any medium, provided the original work is properly cited.

\begin{abstract}
Human interferon alpha (hIFN $\alpha$ ) is a wide biological activity cytokine that is used in hepatitis and cancer treatments. It regulates many genes that are involved in antiviral and antiproliferative activities. This mini review focuses on human interferon alpha-2b (hIFN $\alpha-2 b)$ as therapeutic protein for cancer treatment. The review covers hIFN $\alpha$-2b molecular characteristic and its molecular mechanism by Janus activated kinase/signal transducer activation of transcription (JAK-STAT) pathway. The JAK-STAT pathway regulates not only proteins involved in inhibition of proliferation but also apoptosis. As additional discussion of clinical applications, the use of recombinant hIFN $\alpha-2 \mathrm{~b}(\operatorname{rhIFN} \alpha-2 \mathrm{~b})$ as therapeutic protein in several types of cancer is also explained.
\end{abstract}

\section{Introduction}

Cancer is a first cause of death in developed countries and the second cause of death in developing countries. It was reported that approximately 12.7 million cancer cases occur worldwide with 7.6 million of mortality rate. About $64 \%$ of deaths arise in developing countries. Breast cancer in women and lung cancer in men are the biggest cause of death, followed by stomach, liver, cervix, and prostate cancers. Cancer is a disease caused by uncontrolled cell growth. Growth of these cells causes damage to surrounding tissues and spreads to other tissues via the blood or lymphatic circulation $[1,2]$.

Cancer is generally derived from one cell with accumulated changes in several different genes. Mutation can be caused by exposure to carcinogens, radiation, or infection by bacteria and viruses. Accumulation of mutations causing abnormal cell growth is known as premalignancy. Genes that are involved in cancer are divided into two categories: oncogene and tumor suppressor. Protooncogenes are protein-coding genes that promote cell division, including growth factors (e.g., platelet-derived growth factor, epidermal growth factor, and fibroblast growth factor), growth factor receptors (e.g., HER2 ERBB2, ERBB1, and IGF-1R), and proteins in signal transduction pathways (e.g., RAS, ABL, and $\mathrm{RAF}$ ). Oncogenes are the mutated forms of protooncogenes.
Mutation in oncogenes causes different characteristics or overexpression of protein that triggers the growth of abnormal cells. Tumor suppressor genes are protein-coding genes that suppress cell division, such as RB1 and p53. Mutations in tumor suppressor lead to loss of suppressor activity so that the cells become abnormal in growth. Abnormal cells are used as a therapeutic targets for cancer treatment $[2,3]$.

Cancer treatment can be performed in various ways, such as surgery, chemotherapy, radiotherapy, immunotherapy, gene therapy, or protein therapy. Recombinant therapeutic proteins that have been widely used in cancer are enzymes (Elspar, Oncaspar, and Elitek), toxins (denileukin diftitox or ontak), monoclonal antibodies (Zevalin, Mylotarg, Bexxar, Herceptin, Avastin, Erbitux, Rituxan, Vectibix, and Campath), and cytokines (interleukin-2, interferon- $\alpha \mathrm{n} 3$, interferon- $\beta 1$, and interferon- $\alpha 2 \mathrm{~b}$ ). $\operatorname{rhIFN} \alpha-2 \mathrm{~b}$ was first approved as therapeutic protein by United States Food and Drug Administration (FDA) in 1986. It is used for the treatment of hairy cell leukemia and currently as much as 86 countries have been using rhIFN $\alpha-2 b$ in hepatitis and cancer treatments $[1,4]$. rhIFN $\alpha-2 b$ is widely applied in monotherapy or in combination therapy with other drugs. rhIFN $\alpha 2 b$ is combined with ribavirin, lamivudine, or adevofir on hepatitis treatment and combined with cytarabin, 
vinblastine, 5-fluorouracil, tamoxifen, or interleukin-2 on cancer treatment [4-6].

\section{Molecular Characteristics of hIFN $\alpha-2 b$}

The interferons (IFNs) were first introduced in 1957 as antiviral molecules. Based on their receptor types on the cell membrane surface, IFNs are classified into type I and type II. Type I consists of IFN $\alpha, \operatorname{IFN} \beta, \operatorname{IFN} \omega$, and IFN $\tau$, while type II consists of IFN $\gamma$. IFN type I is a family of cytokines in which amino acid sequence similarity reaches $30-80 \%$. Receptors that are recognized by the type I are grouped into two subunits, IFNAR-1 and IFNAR-2. IFNAR-2 consists of three types, namely, IFNAR-2a, IFNAR-2b, and IFNAR-2c, respectively. IFNAR-2c has important role in ligand binding and signal transduction, whereas IFNAR-2a and IFNAR-2b are competitive inhibitors that prevent IFN from binding to IFNAR2 c. IFN $\alpha$ has wide biological activities ranging as antiproliferation, immunomodulation, and antiviral. IFN $\alpha$ coding genes are located on human chromosome number 9. They have no introns and encode polypeptide chain of 165-166 amino acids. Some IFN $\alpha$ s are unglycosylated but some are glycosylated proteins with different degrees of glycosylation [7-9].

$\mathrm{hIFN} \alpha$-2b molecule is a glycoprotein consisting of 166 amino acids with $\mathrm{O}$-glycosylated threonine at position 106. Two disulfide bonds are formed by cysteines at position 1 and 98 as well as 29 and 138 (Figure 1). Bond formed by positions 1 and 98 is not required in biological activity. Amino acid residues that are important in the biological activity are Leu30, Lys31, Arg33, His34, Phe36, Arg120, Lys121, Gln124, Tyr122, Tyr129, Lys131, Glu132, Arg144, and Glu146. Based on crystal structure that is mediated by zinc dimer, each monomer of rhIFN $\alpha-2 b$ consists of five alpha helices (called helix $\mathrm{A}$ to $\mathrm{E}$ ) that are connected by a loop $\mathrm{AB}, \mathrm{BC}, \mathrm{CD}$, and DE. Residues that are important in the structural integrity are Phe36, Tyr122, and Tyr129. Residues that are important in receptor binding are the $\mathrm{AB}$ loop (Arg22, Leu26, Phe27, Leu30, Lys31, Arg33, and His34), helix B (Ser68), helix C (Thr79, Lys83, Tyr85, and Tyr89), D helix (Arg120, lys121, Gln124, Lys131, and Glu132), and helix E (Arg144 and Glu146). Figure 1 shows a structure of $\operatorname{rhIFN} \alpha-2 b[4,10,11]$.

\section{Molecular Mechanism of hIFN $\alpha-2 b$ as Anticancer}

Antiproliferative activity of hIFN- $\alpha$ consists of direct and indirect activities. Direct activity occurs through cancer cell growth inhibition by cell cycle arrest, apoptosis, or differentiation. Indirect activity occurs through activation of immune cells such as T cells and natural killer cells, inhibition of vascularization (antiangiogenesis), and induction of cytokines. The antiproliferative activity is the result of gene expression regulation. It is initiated by signal transduction pathways and transcriptional activation of JAK-STAT. Study of gene expression in melanoma cell lines (WM9), fibrosarcoma (HT1080), embryonic fibroblasts, and human dendritic cells reported that hIFN $\alpha$ s regulate more than 300 genes of signal transduction pathways in cells $[8,12]$.

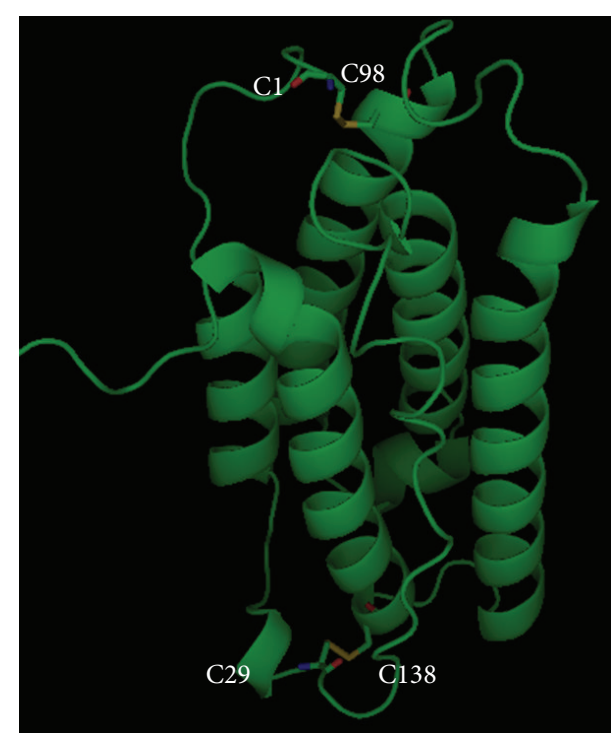

Figure 1: Molecular structure of hIFN $\alpha 2 \mathrm{~b}$ (by PyMOL).

JAK-STAT pathway is initiated by receptors binding on the cell surface. JAK, a tyrosine kinase enzyme, can activate STAT through tyrosine phosphorylation (Figure 2). STAT family consists of seven proteins, namely, STAT-1, STAT-2, STAT-3, STAT-4, STAT-5a, STAT-5b, and STAT-6, respectively and JAK family consists of four proteins, namely, JAK-1, JAK-2, JAK-3, and tyrosine kinase-2 (TYK-2). JAK-1 and TYK- 2 that are activated by IFN $\alpha$ will result in phosphorylation and dimerization. STAT protein-1 (P91) and STAT2 (p113) subsequently translocated with interferon regulating factor-9 (IRF-9 or P48) to the cell nucleus. The protein complex known as IFN-stimulated gene factor 3 (ISGF-3) can activate interferon stimulating response element (ISRE). Two phosphorylated subunits of Stat 1 form alpha activation factor that binds to gamma activation sequence (GAS). These induce transcription of hundreds of interferon-stimulated genes (ISGs) that are involved in antiproliferative as well as antiviral activity $[7,8,13,14]$.

Mechanism of action of hIFN $\alpha 2 b$ in influencing the growth of various cancer cells occurs via the JAK-STAT signal transduction. JAK-STAT pathway related to the MAPK pathway as a major pathway in cell proliferation. MAPK pathway found in all eukaryotic cells and used to control a variety of processes in the cell, such as proliferation, differentiation, survival, and apoptosis. Proteins that play a role in this pathway are protein $G$ and three protein kinases, namely, MAPK kinase kinase (MAPKKK), MAPK kinase (MAPKK), and MAPK. MAPKKK can phosphorylate and activate the MAPK protein kinase (MAPKK), and MAPKK may activate MAPK. hIFN $\alpha 2$ b can inhibit extracellular signal-regulated kinase (ERK) mitogen ERK kinase (MEK) pathway, which includes a group of MAPK pathway. The pathway responds to growth factors and differentiation factors. MEK ERK pathway has Ras as protein G, Raf as MAPKKK, MEK as MAPKK, and ERK as MAPK. At the end of the signal transduction pathway, the transcription factor for mRNA genes synthesis that plays a role in the process of cell division is activated [15-17]. 


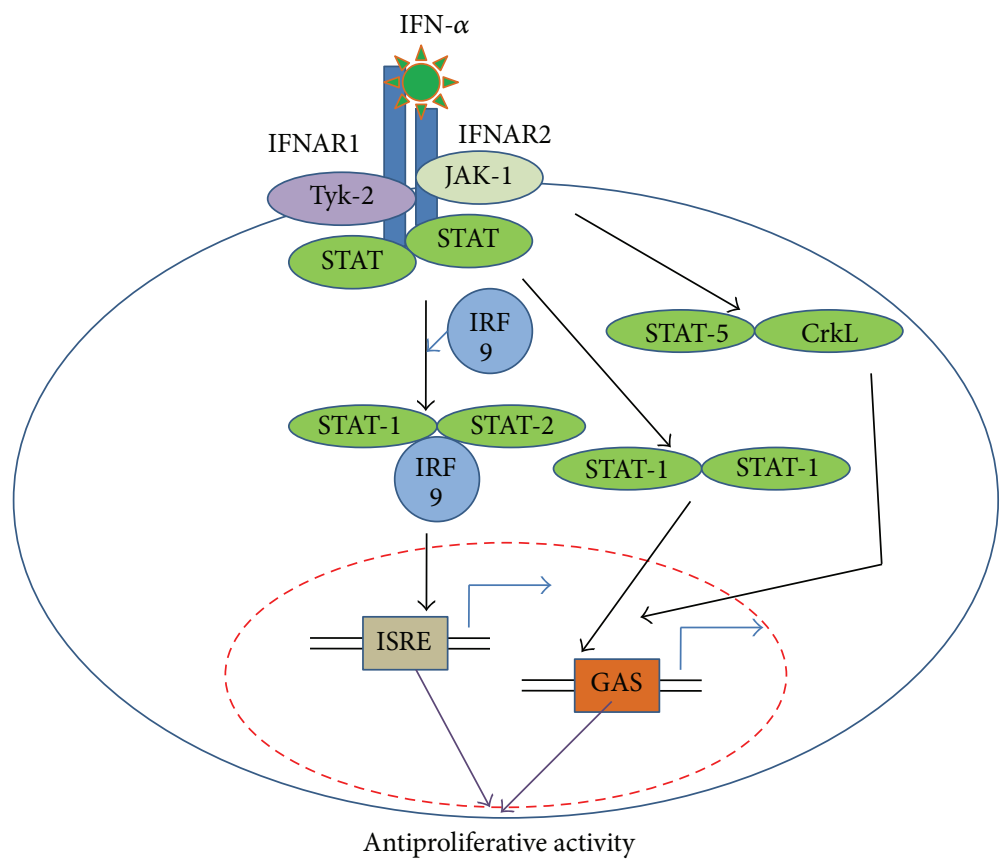

FIGURE 2: IFN $\alpha$-2b signaling via JAK-STAT pathway, adapted from [13].

MEK ERK pathway inhibition by hIFN $\alpha 2$ b has been widely reported. In experiments, using CD 4 + T cells stimulated by anti-CD3 and interleukin-2 (IL-2), it was observed that hIFN $\alpha 2$ b can prevent the G0/G1 phase of the cell cycle from entering $S$ phase. As a result, cells cannot perform DNA replication and proliferation does not occur. Several publications reported that the inhibition of proliferation occurred because $\mathrm{hIFN} \alpha 2 \mathrm{~b}$ may induce enzymes that can inactivate phosphatases PP2A and regulate docking protein that inhibits the interaction of ERK with MEK or MEK interaction with other kinases. Inhibition would decrease the activity of cyclin-dependent protein kinase (CDK-2 and CDK-4) and decreased the expression of cyclin D and E protein as the driving cell division. Inhibition of p21 expression leads to increase p27 Wafl/kip1 (inhibitor of cell division) and decrease phosphorylation of RB/p105 [18, 19].

Mechanism of antiproliferation hIFN $\alpha 2 b$ occurs not only through regulation of protein synthesis and selective translation of proteins involved in inhibition of proliferation, but also through apoptosis as shown in Figure 3. There are two main pathways of apoptosis in cells that are activated: hIFN $\alpha 2 b$ family receptor signal transduction through tumor necrosis factor alpha (TNF- $\alpha$ ) and the release of cytochrome c by mitochondria. Both of these pathways activate caspase signaling cascade resulting in DNA fragmentation and cell death. Induction of cell death occurs through TNF$\alpha$ receptor family, namely, TNF-a/TNF-aR, FasL/Fas, Apol, TRAIL/TRAILR, and Apo2. hIFN $\alpha 2 \mathrm{~b}$ contributes to an increase in p53 protein response to stress signaling and activation of p38 that plays a role in cell death. Additionally, hIFN $\alpha 2 b$ can activate PKR which has a variety of protein substrates such as eukaryotic initiation factor 2 (eIF2), NFKB, IRF-1, p53, STAT1, and NF-90. These proteins may result in the control of cell division, differentiation, and apoptosis. PKR regulates transcription and translation to produce proteins Fas, p53, and Bax can trigger cell death via caspase pathway $[14,20,21]$.

The expression of caspase pathway proteins, such as caspase- 8 and caspase- 9 , caspase- 3 , caspase- 6 , and caspase7 , is also regulated by hIFN $\alpha 2 \mathrm{~b}$. Caspase pathway is initiated by DNA damage signaling. The signal will cut BID protein and alter mitochondrial membrane permeability to release cytochrome c. Cytochrome c protein that activates Apaf1 and caspase-9 will result in cell death. hIFN $\alpha 2$ b also increases the protein expression of caspase-3 and caspase-7 as well as caspase- 8 protein that produces DNA fragmentation. Stimulation of insulin receptor subunit (IRS1 and IRS2) activates phosphatidylinositol3-kinase (PI3K) as an inducer of apoptosis. The role of the PI3K/mTOR pathway in apoptosis remains unclear. PI3K has opposite function. It has been shown to function as a cell survival factor as well as an inducer of apoptosis. In tumor cells, PI3K/mTOR is necessary on apoptosis after treatment with IFN- $\alpha$. The PI3K activation also leads to DNA fragmentation [14].

\section{The Use of hIFN $\alpha$-2b as Therapeutic Protein for Cancer Treatment}

Interferons licensed for antitumor applications are hIFN- $\alpha 2 \mathrm{a}$ (Roferon-A, Hoffmann-La Roche) and hIFN- $\alpha 2 \mathrm{~b}$ (Intron A, Schering-Plough). The most oncological indication of hIFN$\alpha 2 \mathrm{~b}$ includes hairy cell leukemia, melanoma, follicular lymphoma, renal cell carcinoma, AIDS-related Kaposi's sarcoma, and chronic myelogenous leukemia. The clinical applications of rhIFN $\alpha-2 b$ can be summarized in Table 1. 


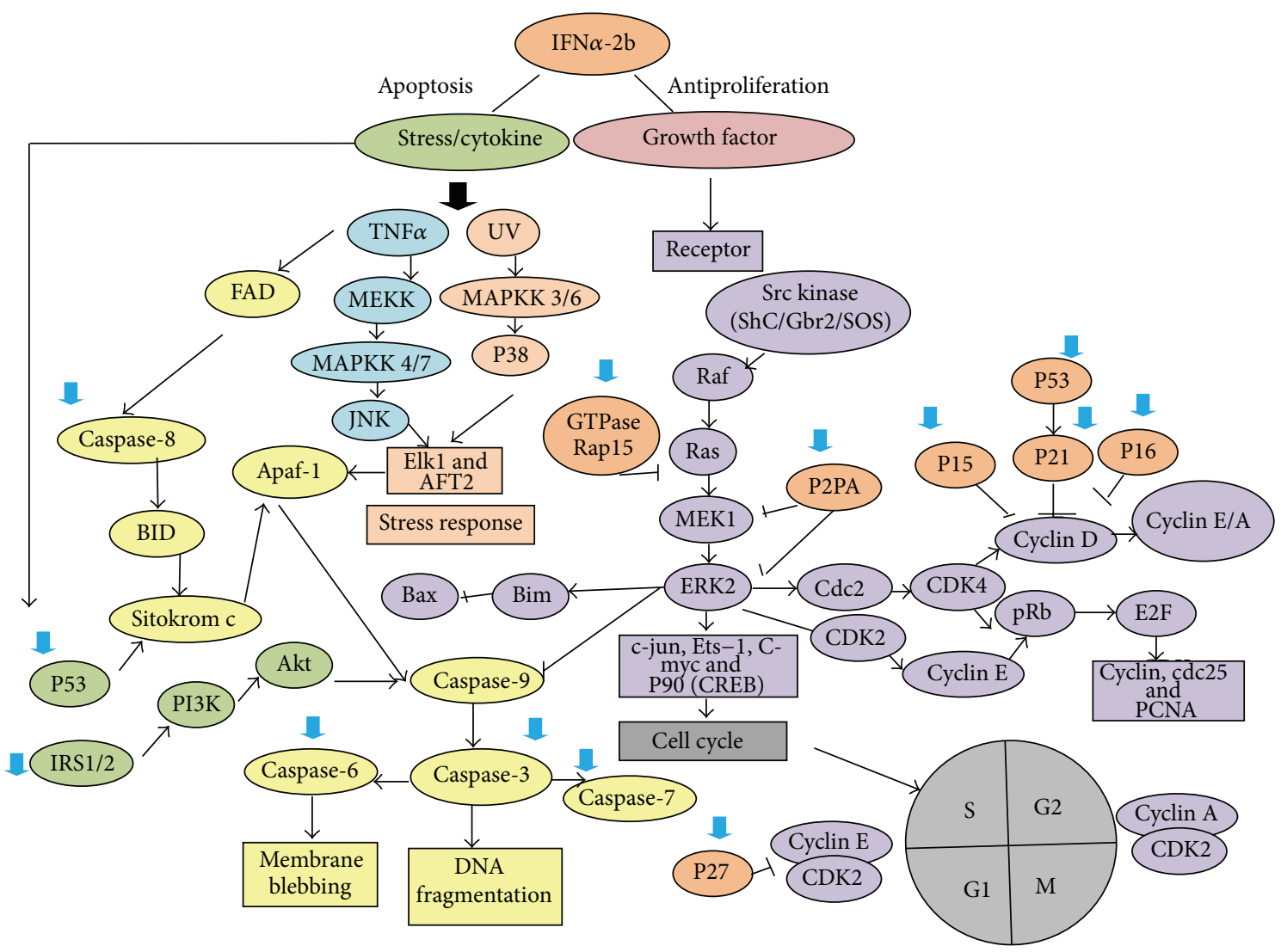

FIGURE 3: Molecular mechanism of hIFN $\alpha-2 b$ as anticancer: apoptosis induction or cell cycle inhibition. The big arrow indicated overexpression of gene that is regulated by hIFN $\alpha-2 b$.

4.1. Hairy Cell Leukemia. Hairy cell leukemia is characterized by mononuclear cells of B-lymphocyte origin in the peripheral blood that have prominent cytoplasmic projections staining with tartrate-resistant acid phosphatase. It is also identified by its typical pattern of infiltration in the bone marrow and spleen. hIFN- $\alpha 2 \mathrm{~b}$ was first approved for use in hairy cell leukemia in 1986. The route of administration for hairy cell leukemia is subcutaneous and the recommended dose is 2 million $\mathrm{U} / \mathrm{m}^{2}$ three times weekly for 12 months [22]. The first report of successful story of IFN was in 1984. Seven patients received 3 million $U$ of partially purified (leukocyte) human IFN intramuscularly daily. Three of seven patients achieved a complete remission and four a partial remission [23]. Purified IFN $\alpha$ - $2 \mathrm{~b}$ synthesized by using recombinant DNA technology (Intron A, Schering Corporation) demonstrates similar activity [24]. It was also reported that $\mathrm{hIFN} \alpha-2 \mathrm{~b}$ was given to 50 patients. The dose was $2.0 \times 10^{6} \mathrm{IU} / \mathrm{m}^{2}$ subcutaneously three times weekly. At 24 months, there were 38 patients remaining. During the two years of continuous IFN treatment none of the patients showed any signs of relapse. The IFN therapy was generally well tolerated, but 24 month evaluation showed mild toxicity in about $76 \%$ of the patients [25]. There was a study which reported unexpected high incidence of second neoplasm in patients after hIFN $\alpha-2 b$ treatments with the same dose for 12 to 18 months of therapy. There were 13 patients from 69 patients (six were hematopoietic origin and the remaining were adenocarcinomas) who developed second neoplasm [26].

4.2. Melanoma. According to the national cancer institute, melanoma is defined as a form of cancer that begins in melanocytes. Melanocytes are cells that make the pigment melanin. Melanoma may begin in a mole (skin melanoma) but can also begin in other pigmented tissues, such as in the eye or in the intestines. The use of high dose of IFN2b for the adjuvant therapy of stage IIB and III melanoma patients was approved by FDA in 1995. A study by Kirkwood et al. [27] in 287 patients compared intravenous administration of hIFN $\alpha$ $2 \mathrm{~b}$ at $20 \mathrm{MU} / \mathrm{m}^{2}$ for 1 month and subcutaneous administration at $10 \mathrm{MU} / \mathrm{m}^{2}$ for 48 weeks with observation alone. It was reported that prolongation of disease-free survival and prolongation of overall survival occurred in comparison to observation. In 1989, the Scottish melanoma group applied a randomized trial to compare observation alone with 6 months' therapy with subcutaneously low dose interferon at $3 \mathrm{MU} /$ day (three times weekly). The result showed that there was a statistically significant improved disease-free survival for up to 24 months [28]. A Systematic Review of Randomized Controlled Trials by Lens and Dawes [29] stated that there was no clear benefit of hIFN $\alpha$-2b on overall survival in melanoma patients. A large randomized controlled trial is needed to study the effectiveness and beneficiary of hIFN $\alpha$ $2 \mathrm{~b}$ treatment. 
TABLE 1: Summary of clinical application of rhIFN $\alpha-2 b$.

\begin{tabular}{|c|c|c|c|c|}
\hline No & Indication & Clinical setting & Efficacy & References \\
\hline \multirow{3}{*}{1} & \multirow{3}{*}{$\begin{array}{l}\text { Hairy cell } \\
\text { leukemia }\end{array}$} & $\begin{array}{l}\text { Seven patients received } 3 \text { million U of } \\
\text { partially purified (leukocyte) human IFN } \\
\text { intramuscularly daily. }\end{array}$ & $\begin{array}{l}\text { Three of seven patients achieved a complete } \\
\text { remission and four a partial remission. }\end{array}$ & [23] \\
\hline & & $\begin{array}{l}\text { hIFN } \alpha-2 \mathrm{~b} \text { was given to } 50 \text { patients. The dose } \\
\text { was } 2.0 \times 10^{6} \mathrm{IU} / \mathrm{m}^{2} \text { subcutaneously three } \\
\text { times weekly. }\end{array}$ & $\begin{array}{l}\text { At } 24 \text { months, there were } 38 \text { patients } \\
\text { remained. During the two years of } \\
\text { continuous IFN treatment none of the } \\
\text { patients showed any signs of relapse. The } \\
\text { IFN therapy was generally well tolerated, but } \\
24 \text { month evaluation showed mild toxicity in } \\
\text { about } 76 \% \text { of the patients. }\end{array}$ & {$[25]$} \\
\hline & & $\begin{array}{l}\text { hIFN } \alpha \text { - } 2 \mathrm{~b} \text { treatments with } 2.0 \times 10^{6} \mathrm{IU} / \mathrm{m}^{2} \\
\text { dose for } 12 \text { to } 18 \text { month therapy. }\end{array}$ & $\begin{array}{l}\text { There were } 13 \text { patients from } 69 \text { patients (six } \\
\text { were hematopoietic origin and the } \\
\text { remaining were adenocarcinomas) } \\
\text { developed second neoplasm. }\end{array}$ & {$[26]$} \\
\hline \multirow{3}{*}{2} & \multirow{3}{*}{ Melanoma } & $\begin{array}{l}\text { Comparing intravenous administration of } \\
\text { hIFN } \alpha-2 \mathrm{~b} \text { at } 20 \mathrm{MU} / \mathrm{m}^{2} \text { for } 1 \text { month and } \\
\text { subcutaneous administration at } 10 \mathrm{MU} / \mathrm{m}^{2} \\
\text { for } 48 \text { weeks with observation alone in } 287 \\
\text { patients. }\end{array}$ & $\begin{array}{l}\text { Prolongation of disease free survival and } \\
\text { prolongation of overall survival occurred in } \\
\text { comparison to observation. }\end{array}$ & [27] \\
\hline & & $\begin{array}{l}\text { A randomized trial to compare observation } \\
\text { alone with } 6 \text { months' therapy with } \\
\text { subcutaneously low dose interferon at } \\
3 \mathrm{MU} / \text { day (three times weekly). }\end{array}$ & $\begin{array}{l}\text { There was a statistically significant improved } \\
\text { disease-free survival for up to } 24 \text { months. }\end{array}$ & {$[28]$} \\
\hline & & $\begin{array}{l}\text { A Systematic Review of Randomized } \\
\text { Controlled Trials by Lens and Dawes. }\end{array}$ & $\begin{array}{l}\text { No clear benefit of hIFN } \alpha-2 \mathrm{~b} \text { on overall } \\
\text { survival in melanoma patients. A large } \\
\text { randomized controlled trial is needed to } \\
\text { study the effectiveness and beneficiary of } \\
\text { hIFN } \alpha \text { - } 2 \text { b treatment. }\end{array}$ & [29] \\
\hline \multirow{3}{*}{3} & \multirow{3}{*}{$\begin{array}{l}\text { Follicular } \\
\text { Lymphoma }\end{array}$} & $\begin{array}{l}\text { IFN } \alpha 2 \mathrm{~b} \text { has given in the context of relatively } \\
\text { intensive initial chemotherapy at } 36 \times 10^{6} \\
\text { units per month. }\end{array}$ & $\begin{array}{l}\text { Prolongation of survival and remission } \\
\text { duration. }\end{array}$ & {$[30]$} \\
\hline & & $\begin{array}{l}\text { Rituximab added to first-line mitoxantrone, } \\
\text { chlorambucil, and prednisolone } \\
\text { chemotherapy followed by interferon } \\
\text { maintenance. }\end{array}$ & $\begin{array}{l}\text { Prolongs survival in patients with advanced } \\
\text { follicular lymphoma. }\end{array}$ & {$[31]$} \\
\hline & & $\begin{array}{l}\text { Stage III or stage IV of } 204 \text { patients that } \\
\text { receive either chlorambucil (CB): } 10 \text { mg } \\
\text { daily for } 6 \text { weeks, followed by a } 2 \text {-week } \\
\text { interval, with } 3 \text { subsequent } 2 \text {-week } \\
\text { treatment periods at the same dose, } \\
\text { separated by 2-week intervals, or, CB given } \\
\text { concurrently with interferon (IFN). IFN was } \\
\text { given at a dose of } 3 \text { million units thrice } \\
\text { weekly, subcutaneously, throughout the } \\
\text { 18-week treatment period. }\end{array}$ & $\begin{array}{l}\text { The role of interferon as initial and } \\
\text { maintenance therapy in patients with newly } \\
\text { diagnosed FL did not demonstrate any } \\
\text { advantage. }\end{array}$ & {$[32]$} \\
\hline \multirow[t]{2}{*}{4} & \multirow[t]{2}{*}{$\begin{array}{l}\text { Renal Cell } \\
\text { Carcinoma }\end{array}$} & $\begin{array}{l}\text { Long term of combination } \mathrm{hIFN} \alpha-2 \mathrm{~b} \text { and } \\
\text { interleukin- } 2 \text { administered subcutaneously } \\
\text { in } 50 \text { patients. }\end{array}$ & $\begin{array}{l}\text { Objective responses was observed in } 9 \text { of } 50 \\
(18 \%) \text { patients and } 6 \text { of whom }(12 \%) \\
\text { achieved a complete response. Overall } \\
\text { median survival is } 12 \text { months, six patients } \\
\text { were surviving at a median follow-up of } 24 \\
\text { months, and three }(6 \%) \text { are still } \\
\text { progression-free. }\end{array}$ & {$[33]$} \\
\hline & & $\begin{array}{l}\text { Nephrectomy followed by hIFN } \alpha-2 b \\
\text { administration. }\end{array}$ & $\begin{array}{l}\text { Improved survival of } 120 \text { metastatic RCC } \\
\text { patients. }\end{array}$ & {$[35]$} \\
\hline
\end{tabular}


TABLE 1: Continued.

\begin{tabular}{|c|c|c|c|c|}
\hline No & Indication & Clinical setting & Efficacy & References \\
\hline \multirow[t]{2}{*}{5} & \multirow[t]{2}{*}{$\begin{array}{l}\text { AIDS-related } \\
\text { Kaposi's } \\
\text { Sarcoma }\end{array}$} & $\begin{array}{l}\text { Treatment of Kaposi's sarcoma with } \\
\text { hIFN } \alpha \text { - } 2 \text { b in } 114 \text { patients using three dose } \\
\text { regimens, that is, } 50 \times 10^{6} \mathrm{IU} / \mathrm{m}^{2} \\
\text { intravenously (high dose), } 30 \times 10^{6} \mathrm{IU} / \mathrm{m}^{2} \\
\text { subcutaneously (intermediate dose), or } 1 \times \\
10^{6} \mathrm{IU} / \mathrm{m}^{2} \text { subcutaneously (low dose). }\end{array}$ & $\begin{array}{l}\text { Complete or partial remissions were } \\
\text { obtained in } 35 \% \text { of the patients. }\end{array}$ & {$[36]$} \\
\hline & & $\begin{array}{l}\text { Combination low dose of hIFN } \alpha-2 \mathrm{~b} \text { with } \\
\text { zidovudine that administered } 10-20 \mathrm{MU} \\
\text { day }^{-1} \text { of hIFN } \alpha \text { and } 500-800 \mathrm{mg} \mathrm{day}^{-1} \\
\text { zidovudin in fourty AIDS-associated } \\
\text { Kaposi's sarcoma patients. }\end{array}$ & $\begin{array}{l}\text { Eighteen patients ( } 45 \%) \text { had an overall } \\
\text { response }(\mathrm{CR}+\mathrm{PR}) \text { at } 3 \text { months and a } \\
\text { response persisting for a median of } 14(3-27) \\
\text { months. }\end{array}$ & {$[37]$} \\
\hline \multirow[t]{2}{*}{6} & \multirow{2}{*}{$\begin{array}{l}\text { Chronic } \\
\text { Myelogenous } \\
\text { Leukemia }\end{array}$} & $\begin{array}{l}114 \text { patients with chronic myelogenous } \\
\text { leukaemia in India. All patients were } \\
\text { received } 5 \text { million unit of rhIFN } \alpha \text {-2b daily } \\
\text { subcutaneously. }\end{array}$ & $\begin{array}{l}\text { Kaplan-Meier probability of survival at } 36 \\
\text { months was } 76 \% \text {. }\end{array}$ & [39] \\
\hline & & $\begin{array}{l}82 \text { Ph'positive CML patients that had } \\
\text { intermittent or daily administration of } \\
\text { rhIFN } \alpha-2 b \text {. }\end{array}$ & $\begin{array}{l}\text { The rate of cytogenetic response and } \\
\text { patients survival were increased when } \\
\text { rhIFN } \alpha \text { - } 2 \text { b was combined with cytarabine. }\end{array}$ & {$[40]$} \\
\hline
\end{tabular}

4.3. Follicular Lymphoma. National cancer institute defines follicular lymphoma (FL) as a type of B-cell non-Hodgkin lymphoma that is usually indolent. The tumor cells grow as groups to form nodules. A meta-analysis to evaluate the role of hIFN $\alpha 2$ in FL reported prolongation of survival and remission duration when it has been given in the context of relatively intensive initial chemotherapy at $36 \times 10^{6}$ units per month [30]. An East german study stated that rituximab added to first-line mitoxantrone, chlorambucil, and prednisolone chemotherapy followed by interferon maintenance prolongs survival in patients with advanced follicular lymphoma [31]. Another research reported that the role of interferon as initial and maintenance therapy in patients with newly diagnosed FL did not demonstrate any advantage. This study observed stage III or stage IV of 204 patients that receive either chlorambucil $(\mathrm{CB}), 10 \mathrm{mg}$ daily for 6 weeks, followed by a 2 -week interval, with 3 subsequent 2 -week treatment periods at the same dose, separated by 2 -week intervals, or CB given concurrently with interferon (IFN). IFN was given at a dose of 3 million units thrice weekly, subcutaneously, throughout the 18-week treatment period [32].

4.4. Renal Cell Carcinoma. The definition of renal cell carcinoma (RCC) according to the national cancer institute is a cancer that forms in the lining of very small tubes in the kidney that filter the blood and remove waste products. Long term results of combination of hIFN $\alpha 2 b$ and interleukin2 administered subcutaneously in advanced renal cell carcinoma showed an improved survival for advanced RCC $[33,34]$. Locatelli's study [33] stated that objective responses were observed in 9 of 50 (18\%) patients and 6 of whom (12\%) achieved a complete response. Overall median survival is 12 months; six patients were surviving at a median follow-up of 24 months, and three $(6 \%)$ are still progression-free. It was also reported that nephrectomy followed by hIFN $\alpha 2 b$ administration improved survival of 120 metastatic RCC patients [35].
4.5. AIDS-Related Kaposi's Sarcoma. Kaposi's sarcoma is a form of skin cancer that can involve internal organs and mostly is found in acquired immunodeficiency syndrome patients. Treatment of Kaposi's sarcoma with hIFN $\alpha$-2b in 114 patients using three dose regimens, that is, $50 \times 10^{6} \mathrm{IU} / \mathrm{m}^{2}$ intravenously (high dose), $30 \times 10^{6} \mathrm{IU} / \mathrm{m}^{2}$ subcutaneously (intermediate dose), or $1 \times 10^{6} \mathrm{IU} / \mathrm{m}^{2}$ subcutaneously (low dose). Clinical responses were seen in all regimens and complete or partial remissions were obtained in 35\% of the patients. In this study, it was known that high-dose therapy was associated with more rapid time to response [36]. Another study reported that low-dose IFN- $\alpha 2$ b plus zidovudine seems to be a useful and well-tolerated therapy for KS with antitumoral and antiviral activity. This study observed the effect of combination of low dose of hIFN $\alpha$ $2 \mathrm{~b}$ with zidovudine that administered 10-20 MU day ${ }^{-1}$ of hIFN $\alpha$ and $500-800 \mathrm{mg}$ day $^{-1}$ zidovudine in forty AIDSassociated Kaposi's sarcoma patients. Eighteen patients (45\%) had an overall response $(\mathrm{CR}+\mathrm{PR})$ at 3 months and a response persisting for a median of 14 (3-27) months [37].

4.6. Chronic Myelogenous Leukemia. Chronic myelocytic leukemia (CML) is a cancer of white blood cells in which too many white blood cells are made in the bone marrow. The disease mostly characterized cytogenetically by the presence of the Philadelphia chromosome (Ph) $(9 ; 22)(\mathrm{q} 34 ; \mathrm{q} 11)$ in $90 \%-95 \%$ of patients [38]. A study of safety and efficacy of an indigenous rhIFN $\alpha$-2b was conducted in 114 patients with chronic myelogenous leukaemia in India. All patients received 5 million units of rhIFN $\alpha$-2b daily subcutaneously. The result confirmed that the protein efficacy with KaplanMeier probability of survival at 36 months was 76\% [39]. Another study was applied in $82 \mathrm{Ph}$-positive CML patients that had intermittent or daily administration of $\operatorname{rhIFN} \alpha$ $2 b$. The study reported the effectiveness of $\operatorname{rhIFN} \alpha-2 b$ in inducing clinical and cytogenetic response [38]. The rate of 
cytogenetic response and patients' survival increased when rhIFN $\alpha-2 b$ was combined with cytarabine [40].

\section{Conclusions and Future Directions}

hIFN $\alpha-2 b$ is a protein that has anticancer activity. It has been approved by the FDA as a therapeutic protein that can be used to treat some types of cancer, either in monotherapy or combination therapy with other anticancer drugs. The information regarding the side effects of $\operatorname{rhIFN} \alpha-2 b$ needs to be well known because its therapeutic use requires a long time. Development of rhIFN $\alpha-2 b$ to improve the efficacy and safety of proteins is very important. The continuous further exploration on $\operatorname{rhIFN} \alpha-2 b$ will lead to the improvement of patient's life quality.

\section{Conflict of Interests}

The author declares that there is no conflict of interests regarding the publication of this paper.

\section{References}

[1] A. Jemal, F. Bray, M. M. Center, J. Ferlay, E. Ward, and D. Forman, "Global cancer statistics," CA: A Cancer Journal for Clinicians, vol. 61, no. 2, pp. 69-90, 2011.

[2] F. Macdonald and C. H. J. Ford, Molecular Biology of Cancer, BIOS Scientific, New York, NY, USA, 1st edition, 1997.

[3] B. A. J. Ponder, "Molecular genetics of cancer," British Medical Journal, vol. 304, no. 6836, pp. 1234-1236, 1992.

[4] Y.-S. Wang, S. Youngster, M. Grace, J. Bausch, R. Bordens, and D. F. Wyss, "Structural and biological characterization of pegylated recombinant interferon alpha- $2 \mathrm{~b}$ and its therapeutic implications," Advanced Drug Delivery Reviews, vol. 54, no. 4, pp. 547-570, 2002.

[5] B. Leader, Q. J. Baca, and D. E. Golan, "Protein therapeutics: a summary and pharmacological classification," Nature Reviews Drug Discovery, vol. 7, no. 1, pp. 21-39, 2008.

[6] P. Buckel, "Recombinant proteins for therapy," Trends in Pharmacological Sciences, vol. 17, no. 12, pp. 450-456, 1996.

[7] E. Jonasch and F. G. Haluska, "Interferon in oncological practice: review of interferon biology, clinical applications, and toxicities," The Oncologist, vol. 6, no. 1, pp. 34-55, 2001.

[8] C. E. Samuel, "Antiviral actions of interferons," Clinical Microbiology Reviews, vol. 14, no. 4, pp. 778-809, 2001.

[9] T. A. Nyman, N. Kalkkinen, H. Tölö, and J. Helin, "Structural characterisation of $\mathrm{N}$-linked and O-linked oligosaccharides derived from interferon- $\alpha 2 \mathrm{~b}$ and interferon- $\alpha 14 \mathrm{c}$ produced by Sendai-virus- induced human peripheral blood leukocytes," European Journal of Biochemistry, vol. 253, no. 2, pp. 485-493, 1998.

[10] F. O. Neves, P. L. Ho, I. Raw, C. A. Pereira, C. Moreira, and A. L. T. O. Nascimento, "Overexpression of a synthetic gene encoding human alpha interferon in Escherichia coli," Protein Expression and Purification, vol. 35, no. 2, pp. 353-359, 2004.

[11] R. Radhakrishnan, L. J. Walter, A. Hruza et al., "Zinc mediated dimer of human interferon- $\alpha(2 \mathrm{~b})$ revealed by X-ray crystallography," Structure, vol. 4, no. 12, pp. 1453-1463, 1996.
[12] M. C. Sarkar, D. J. Lindner, Y.-F. Liu et al., "Apoptosis and interferons: role of interferon-stimulated genes as mediators of apoptosis," Apoptosis, vol. 8, no. 3, pp. 237-249, 2003.

[13] B. Gao, F. Hong, and S. dan Radaeva, "Host factors and failure of interferon- $\alpha$ treatment in hepatitis C Virus," Hepatology, vol. 39, no. 4, pp. 880-890, 2004.

[14] J. Bekisz, S. Baron, C. Balinsky, A. Morrow, and K. C. dan Zoon, "Antiproliferative properties of type I and type II interferon," Pharmaceuticals, vol. 3, no. 4, pp. 994-1015, 2010.

[15] M. Chiariello, E. Gomez, and J. S. Gutkind, "Regulation of cyclin-dependent kinase (Cdk) 2 Thr-160 phosphorylation and activity by mitogen-activated protein kinase in late G1 phase," Biochemical Journal, vol. 349, no. 3, pp. 869-876, 2000.

[16] W. Kolch, "Meaningful relationships: the regulation of the Ras/Raf/MEK/ERK pathway by protein interactions," Biochemical Journal, vol. 351, no. 2, pp. 289-305, 2000.

[17] F. Romerio and D. dan Zella, "MEK and ERK inhibitors enhance the anti-proliferative effect of interferon-alpha2b," The FASEB Journal, vol. 16, no. 12, pp. 1680-1682, 2002.

[18] F. Romerio, A. Riva, and D. dan Zella, "Interferon- $\alpha 2 \mathrm{~b}$ reduces phosphorylation and activity of MEK and ERK through a Ras/Raf-independent mechanism," British Journal of Cancer, vol. 83, no. 4, pp. 532-538, 2000.

[19] L. S. Steelman, S. C. Pohnert, J. G. Shelton, R. A. Franklin, F. E. Bertrand, and J. A. McCubrey, "JAK/STAT, Raf/MEK/ERK, PI3K/Akt and BCR-ABL in cell cycle progression and leukemogenesis," Leukemia, vol. 18, no. 2, pp. 189-218, 2004.

[20] P. Tagliaferri, M. Caraglia, A. Budillon et al., "New pharmacokinetic and pharmacodynamic tools for interferon-alpha (IFN- $\alpha$ ) treatment of human cancer," Cancer Immunology, Immunotherapy, vol. 54, no. 1, pp. 1-10, 2005.

[21] E. D. Bazhanova, "Participation of interferon-alpha in regulation of apoptosis," Journal of Evolutionary Biochemistry and Physiology, vol. 41, no. 2, pp. 127-133, 2005.

[22] A. Saven and L. D. Piro, "Treatment of hairy cell leukemia," Blood, vol. 79, no. 5, pp. 1111-1120, 1992.

[23] J. R. Quesada, J. Reuben, and J. T. Manning, "Alpha interferon for induction of remission in hairy-cell leukemia," The New England Journal of Medicine, vol. 310, no. 1, pp. 15-18, 1984.

[24] M. J. Ratain, H. M. Golomb, J. W. Vardiman et al., "Relapse after interferon alfa-2b therapy for hairy-cell leukemia: analysis of prognostic variables," Journal of Clinical Oncology, vol. 6, no. 11, pp. 1714-1721, 1988.

[25] I. Braide, J. Westin, H. Hasselbalch et al., "Demonstrated benefit of continuous interferon-alpha-2b therapy in hairy cell leukemia. A two-year follow-up," Leukemia and Lymphoma, vol. 5, no. 1, pp. 23-31, 1991.

[26] P. Kampmeier, R. Spielberger, J. Dickstein, R. Mick, H. Golomb, and J. W. Vardiman, "Increased incidence of second neoplasms in patients treated with interferon $\alpha 2 \mathrm{~b}$ for hairy cell leukemia: a clinicopathologic assessment," Blood, vol. 83, no. 10, pp. 29312938, 1994.

[27] J. M. Kirkwood, M. H. Strawderman, M. S. Ernstoff, T. J. Smith, E. C. Borden, and R. H. Blum, "Interferon alfa-2b adjuvant therapy of high-risk resected cutaneous melanoma: the Eastern Cooperative Oncology Group trial EST 1684," Journal of Clinical Oncology, vol. 14, no. 1, pp. 7-17, 1996.

[28] D. A. Cameron, M. C. Cornbleet, R. M. Mackie, J. A. A. Hunter, M. Gore, and B. Hancock, "Adjuvant interferon alpha $2 \mathrm{~b}$ in high risk melanoma-the scottish study," British Journal of Cancer, vol. 84, no. 9, pp. 1146-1149, 2001. 
[29] M. B. Lens and M. Dawes, "Interferon alfa therapy for malignant melanoma: a systematic review of randomized controlled trials," Journal of Clinical Oncology, vol. 20, no. 7, pp. 1818-1825, 2002.

[30] A. Z. S. Rohatiner, W. M. Gregory, B. Peterson et al., "Metaanalysis to evaluate the role of interferon in follicular lymphoma," Journal of Clinical Oncology, vol. 23, no. 10, pp. 22152223, 2005.

[31] M. Herold, A. Haas, S. Srock et al., "Rituximab added to firstline mitoxantrone, chlorambucil, and prednisolone chemotherapy followed by interferon maintenance prolongs survival in patients with advanced follicular lymphoma: an East German study group hematology and oncology study," Journal of Clinical Oncology, vol. 25, no. 15, pp. 1986-1992, 2007.

[32] A. Rohatiner, J. Radford, D. Deakin et al., "A randomized controlled trial to evaluate the role of interferon as initial and maintenance therapy in patients with follicular lymphoma," British Journal of Cancer, vol. 85, no. 1, pp. 29-35, 2001.

[33] M. C. Locatelli, G. Facendola, G. Pizzocaro et al., "Subcutaneous administration of interleukin- 2 and interferon- $\alpha 2 b$ in advanced renal cell carcinoma: long-term results," Cancer Detection and Prevention, vol. 23, no. 2, pp. 172-176, 1999.

[34] J. Atzpodien, R. Hoffmann, M. Franzke, C. Stief, T. Wandert, and M. Reitz, "Thirteen-year, long-term efficacy of interferon $2 \alpha$ and interleukin 2-based home therapy in patients with advanced renal cell carcinoma," Cancer, vol. 95, no. 5, pp. 10451050, 2002.

[35] R. C. Flanigan, S. E. Salmon, B. A. Blumenstein et al., "Nephrectomy followed by interferon alfa-2b compared with interferon alfa- $2 \mathrm{~b}$ alone for metastatic renal-cell cancer," The New England Journal of Medicine, vol. 345, no. 23, pp. 1655-1659, 2001.

[36] P. A. Volberding, R. T. Mitsuyasu, J. P. Golando, and R. J. Spiegel, "Treatment of Kaposi's sarcoma with interferon alfa2b (Intron A)," Cancer, vol. 59, pp. 620-625, 1987.

[37] D. Podzamczer, F. Bolao, B. Clotet et al., "Low-dose interferon alpha combined with zidovudine in patients with AIDSassociated Kaposi's sarcoma," Journal of Internal Medicine, vol. 223, no. 3, pp. 247-253, 1993.

[38] L. Kumar, V. P. Gangadharan, D. Raghunadha Rao et al., "Safety and efficacy of an indigenous recombinant interferon-alpha- $2 b$ in patients with chronic myelogenous leukaemia: results of a multicentre trial from India," The National Medical Journal of India, vol. 18, no. 2, pp. 66-70, 2005.

[39] G. Alimena, E. Morra, M. Lazzarino et al., "Interferon alpha$2 \mathrm{~b}$ as therapy for Ph'-positive chronic myelogenous leukemia: a study of 82 patients treated with intermittent or daily administration," Blood, vol. 72, no. 2, pp. 642-647, 1988.

[40] F. Guilhot, C. Chastang, M. Michallet et al., "Interferon alfa$2 \mathrm{~b}$ combined with cytarabine versus interferon alone in chronic myelogenous leukemia," The New England Journal of Medicine, vol. 337, no. 4, pp. 223-229, 1997. 

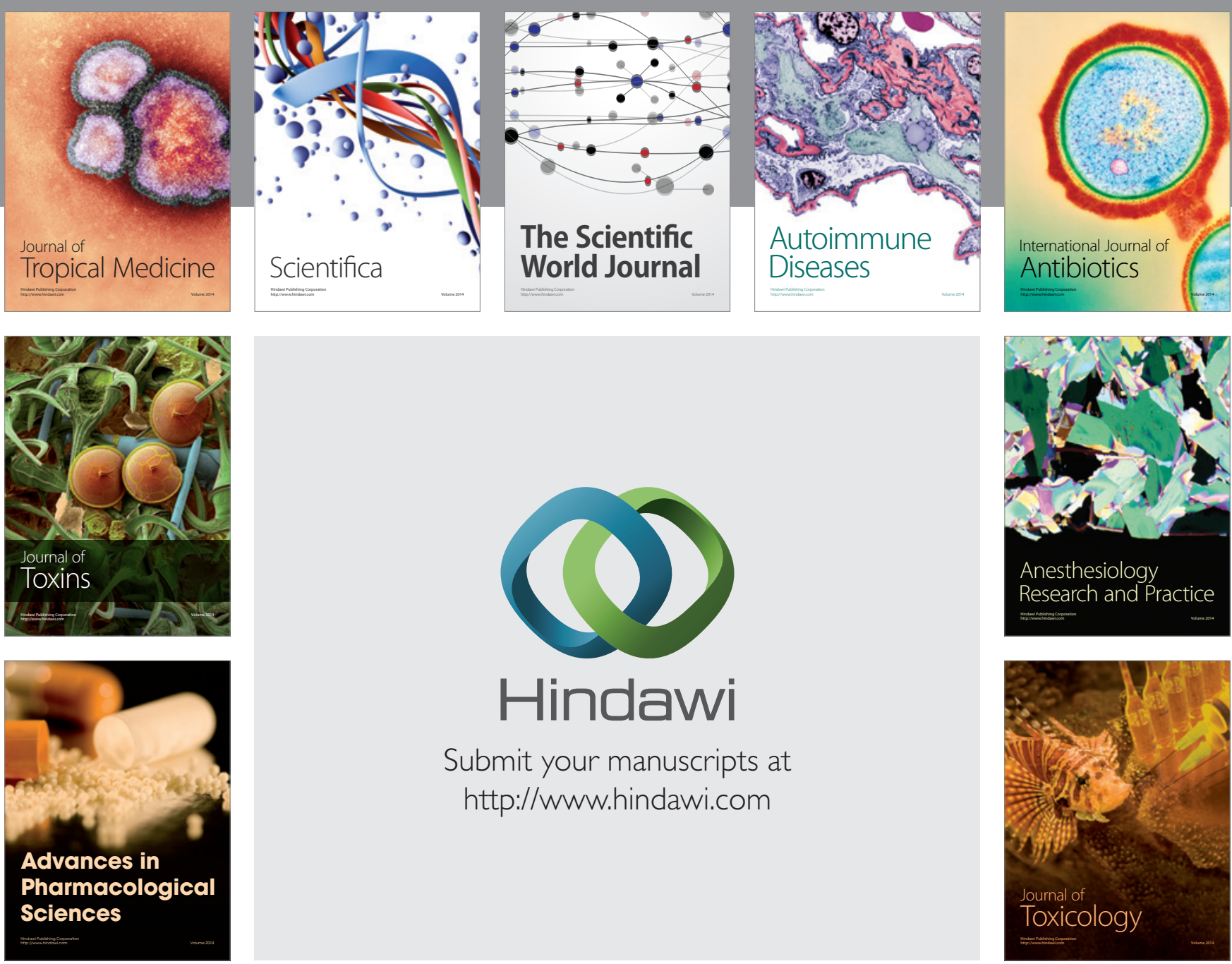

\section{Hindawi}

Submit your manuscripts at

http://www.hindawi.com
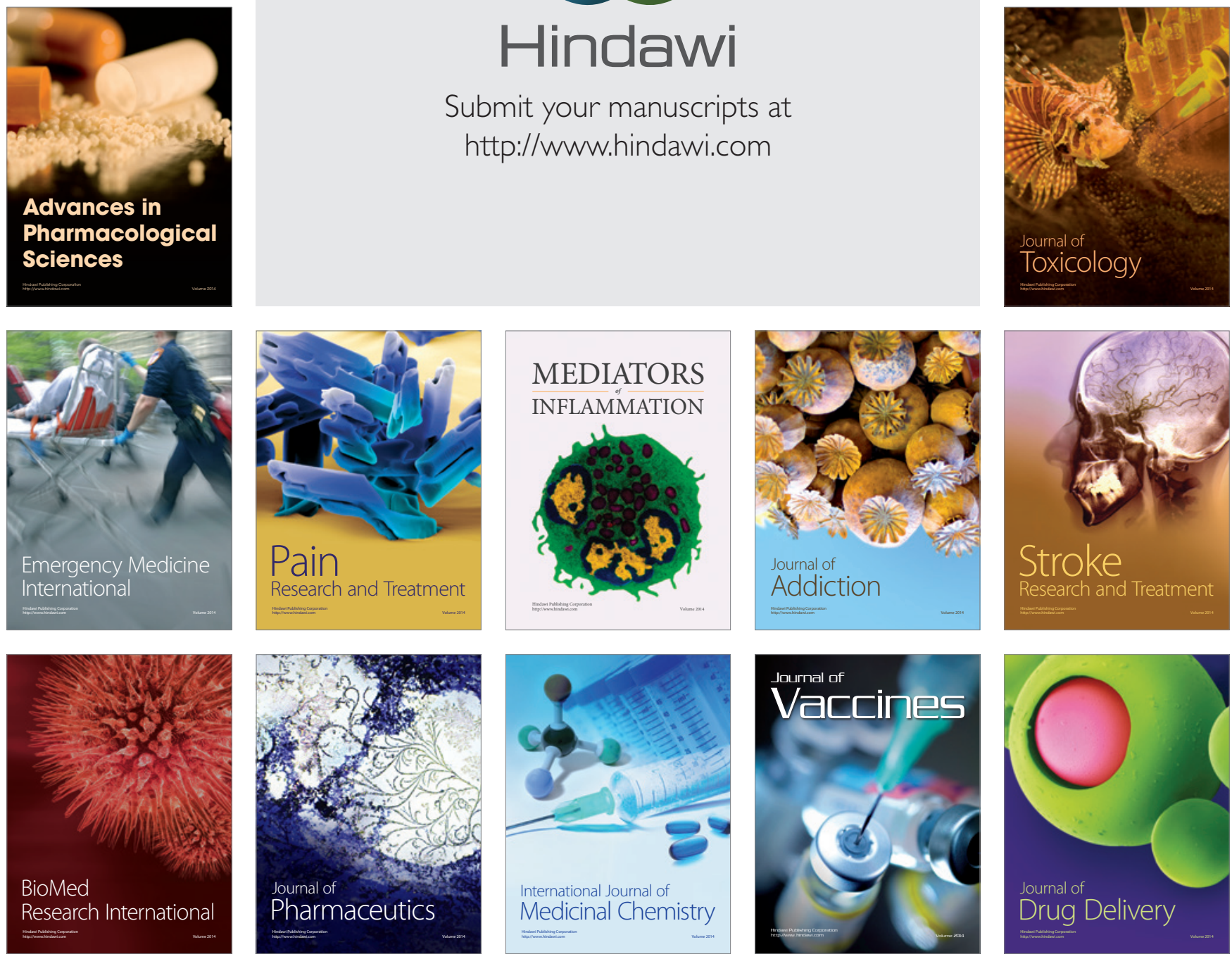